\title{
The challenges facing the Dutch Reformed Churches in the South African liberal democracy
}

\begin{tabular}{|c|c|}
\hline $\begin{array}{l}\text { Author: } \\
\text { Motshine A. }\end{array}$ & ekhaulelo ${ }^{1}$ \\
\hline $\begin{array}{l}\text { Affiliation: } \\
{ }^{1} \text { Department } \\
\text { Christian Ethi } \\
\text { Theology, Un } \\
\text { Pretoria, Sou }\end{array}$ & $\begin{array}{l}\text { Dogmatics and } \\
\text { s, Faculty of } \\
\text { lersity of } \\
\text { Africa }\end{array}$ \\
\hline $\begin{array}{l}\text { Project leade } \\
\text { Project numb }\end{array}$ & $\begin{array}{l}\text { W. Fourie } \\
\text { er: } 04497849\end{array}$ \\
\hline $\begin{array}{l}\text { Description: } \\
\text { Dr Sekhaulelc } \\
\text { in the researc } \\
\text { 'Social ethics } \\
\text { flux', directed } \\
\text { Fourie, Depar } \\
\text { Dogmatics an } \\
\text { Ethics, Facult } \\
\text { University of }\end{array}$ & $\begin{array}{l}\text { is participating } \\
\text { project, } \\
\text { or regions in } \\
\text { by Dr Willem } \\
\text { ment } \\
\text { Christian } \\
\text { of Theology, } \\
\text { retoria. }\end{array}$ \\
\hline $\begin{array}{l}\text { Correspondin } \\
\text { Motshine Sek } \\
\text { amos.motshir }\end{array}$ & $\begin{array}{l}\text { g author: } \\
\text { haulelo, } \\
\text { e@gmail.com }\end{array}$ \\
\hline $\begin{array}{l}\text { Dates: } \\
\text { Received: } 08 \\
\text { Accepted: } 24 \\
\text { Published: } 31\end{array}$ & $\begin{array}{l}\text { May } 2015 \\
\text { Aec. } 2015 \\
\text { Aug. } 2016\end{array}$ \\
\hline $\begin{array}{l}\text { How to cite } t \\
\text { Sekhaulelo, } \\
\text { challenges fa } \\
\text { Reformed Ch } \\
\text { South African } \\
\text { democracy', } \\
\text { Studies/Theo } \\
72(1) \text {, a3031. } \\
\text { org/10.4102/ }\end{array}$ & $\begin{array}{l}\text { is article: } \\
\text {., 2016, 'The } \\
\text { ing the Dutch } \\
\text { rches in the } \\
\text { liberal } \\
\text { TS Teologiese } \\
\text { gical Studies } \\
\text { ittp://dx.doi. } \\
\text { its.v72i1.3031 }\end{array}$ \\
\hline $\begin{array}{l}\text { Copyright: } \\
\text { (C) 2016. The } \\
\text { Licensee: AOS } \\
\text { is licensed un } \\
\text { Creative Com } \\
\text { Attribution Li }\end{array}$ & $\begin{array}{l}\text { uthors. } \\
\text { S. This work } \\
\text { ler the } \\
\text { nons } \\
\text { ense. }\end{array}$ \\
\hline Read online: & \\
\hline 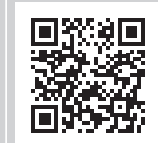 & $\begin{array}{l}\text { Scan this QR } \\
\text { code with your } \\
\text { smart phone or } \\
\text { mobile device } \\
\text { to read online. }\end{array}$ \\
\hline
\end{tabular}

This article investigates the challenges facing the Dutch Reformed Churches in the South African liberal democracy. It is premised on the fact that the Dutch Reformed Churches are confronted with a new context that places the church in a position to continue its work of bearing witness in the new dispensation. Part of this reflection involved seeking out the Biblical principles and guidelines that Christians would have to take into account in association with the new political order.

\section{Introduction}

The Dutch Reformed Church in South Africa is historically divided into three sister churches, namely: the Dutch Reformed Church (Nederduitsch Gereformeerde Kerk), the Dutch Reformed Church in Africa (Nederduitsch Hervormde) and the Dutch Reformed Churches in South Africa (Gereformeerde Kerke in Suid-Afrika) (Giliomee \& Schlemmer 1989:45; Greenway \& Mashau 2007:8; Hofmeyr \& Pillay 1994:12; Nefefe 2000:16; Ryan 1990:40; cf. Van der Walt 2010:136). Mention should also be made that prior to 1994, most Christian churches, with the exception of the Dutch Reformed Churches played a prominent part in the anti-apartheid struggle and many supported the United Democratic Front (UDF). This enabled the African National Congres ANC to establish considerable influence and even control over such key institutions as the South African Council of Churches (SACC) (Johnson 2009:309a). On the other hand, in pre-1994 South Africa the largest group of Christians possessing freedom of speech and the right to vote belonged to the white Dutch Reformed Churches. Through their vote and otherwise, this influential block in general accepted and appeared to give their active support to the undemocratic policy of Apartheid. This is accounted for in many writings, among which Roberts and Brooman (2001:41); cf. Giliomee and Schlemmer (1989:51b); Saul and Bond (2014:25); Venter (1998:18) and Vorster (2004:203).

The question thus remains: How then can the Dutch Reformed Churches offer prophetic witness in the South African society today? In response, this article is structured as follows: (1) introduction, (2) methodology, (3) specific challenges facing the Dutch Reformed Churches, (4) response of the Dutch Reformed Churches and (5) conclusion.

\section{Methodology}

This study is undertaken from a Reformed ethical perspective. Whilst being conscious and aware of other Christian traditions and practices, the author's personal journey of faith as an African Christian and minister of the Word has been formed and shaped by the Reformed faith (Calvinist tradition). As far as the author of this article is concerned, the Bible reveals a level of moral and spiritual guidance that is unparalleled in any literature. However, it does not address every possible question that may be asked. Its purpose is to reveal how God relates to men and how men are to relate to God.

\section{Specific challenges facing the Dutch Reformed Churches}

The church, both in the Old and the New Testament, Biblically addressed a number of ethical and community issues that arose in the early communities, similar to those prevalent in post-1994 South Africa. The author does not claim to be invested with infallible gifts of analysis, but the following can be mentioned with regard to the issue under reflection.

\section{New status of Christianity under the emerging secular state}

South Africa has undergone many changes in the last decade in almost all spheres of life in our country, whether it be politics, economics, social life or religious life (Strydom \& 
Wessels 2000:7a). Until recently, the country was predominated by something similar to the medieval corpus Christianun concept. The point of departure was that South Africa is a Christian country and it was thus expected of the State not only to protect the Christian religion, but also to actively promote it. An example of this is the government's active promotion of Christian (national) education (Biko, 2013:242).

This ideal is however now being displaced by that of a secular state - a community that is officially without any religion or ideology save that of maximising the freedom of citizens to pursue as individuals, whatever interests, religious or otherwise, they happen to have. It is important to note that a distinctive product of Christian civilisation is its concern for the individual's health, welfare and dignity; for integrity in public administration; and for a family life in which womanhood is honoured and children's claims acknowledged. South Africa today is busily secularising these concerns - that is, detaching them from their historic rooting in Christian faith and dismissing that dismissing faith as a viable basis for community life (Heelas, Martin \& Morris 1998:148; Packer 1994:284-285;).

It must be mentioned that prior to 1994 the State was in service to the church in order to protect its members against $\sin ^{\prime}$ (N. Vorster 2007:119). There was a variety of statutes and provincial ordinances that ensured the maintenance of Sundays, by regulating affairs of businesses, entertainment and recreation Sundays (Giliomee \& Schlemmer 1989:83). In the new political dispensation the common Christian basis for discussion between church and state does not exist anymore. Churches can therefore no longer expect the government to protect Christian values through legislation or to enforce a certain Christian morality on society, because this will bring the authorities in conflict with the Constitution. This means that Christianity will no longer have a privileged position in South Africa, and consequently Christians will have to reflect anew on the implication of their faith within the larger society. This reality is exemplified in the State ceasing to employ criminal law to maintain Christian social values (N. Vorster, 2007:89).

The new government has since 1994 legalised unchristian practices such as abortion on request, adult pornography, same-sex marriage (Civil Unions Act) and gambling (cf. Kretzschmar \& Hulley 1998:63a; McCauley \& Steel 1996:57; Rainey \& Magill 1996:96). Even with regard to talks with the government, the church cannot expect preferential treatment anymore. It is then, from this perspective, reasonable to say that the first challenge facing the historical three sister churches is coming to terms with the new status of Christianity under the emerging secular state. This means full recognition that the churches and Christians no longer have the monopoly on matters of ethics and morality in society and can, therefore, no longer impose their will upon other religious and even nonreligious communities.

\section{Religious pluralism}

Popenoe, Boult and Cunningham (1998:363) observe that the South African Constitution lays out the framework for a pluralist system. All people, especially Christians, are exposed to other religions, and for many it was quite a culture shock. For the first time Islam, Hindu and other religions are broadcast on television (Van der Walt \& Swanepoel 1996:28b). It should also be pointed out that pluralism is not just an expression of the number of ethnic or religious groups in society; it also involves the fragmentation of all kinds of beliefs due to the breakdown of shared values and the distrust of any kind of authority, particularly political and religious authority (Gouws \& Kruger 1996:187; McGrath 1992:148). The political, cultural, religious and theological pluralism of the contemporary world constitute moral challenges to the Dutch Reformed Churches. On the one hand, it poses a serious threat to the oneness of the Gospel and the unity of the faith.

Twentieth-century theologians dealt with this issue from diverse perspectives. The two most common responses to this question represent opposite extremes. One is 'imposition', the crusading attempt to coerce people through legislation to accept the Christian way. The other is laissez-faire, the defeatist decision to leave people be and not interfere or endeavour to influence them in any way. Better than the extremes of imposition and laissez-faire is the strategy of persuasion by argument. This is the way the Christian mind advocates, for it arises naturally from the Biblical doctrines of God and human beings. So both the Biblical doctrine of God and that of human beings guide behaviour in a pluralistic society; the former ruling out laissez-faire and the latter ruling out imposition (Stott 2006:78a).

The rich diversity of societal relationship, which has come into being in the course of history, should not mean fragmentation. The different societal structures have to cooperate in a relation of partnership, otherwise the individual man's life disintegrates. In the Reformed tradition this is called the principle of sphere universality. It is important to note that the concept pluralism also, however, includes confessional pluralism. It is not only advocating the right of a diversity of societal relationships, but also the rights and liberties of a diversity of religious convictions (Van der Walt 2007:156). It is clear that religious plurality constitutes the very context of being a church. Our theology, our traditions, our values and our way of life are strongly influenced by our pluralist environment. The church is called to redefine its identity and mission vocation in the midst of religious plurality. We must revisit the Biblical theology and the Logos Christology of the early church, to aid and remind us to examine the basics of our faith in a broader perspective.

\section{The marginalisation of minority}

History has clearly shown that totalitarianism - the attempt to place all aspects of life under the control of a centralised political authority - failed to acknowledge minority rights. 
Mere majority rule in a democracy has also proved to be inadequate and even detrimental to the protection of minority rights. A clear example is the exploitation of white farmers in 2000 in the 'democracy' of Zimbabwe. Although these farmers have the right to vote and to form a political party or to join an opposition party, their numbers are too small to resist the abuse of power by a brutal government effectively (Vorster 2004:170). It is certainly true in South Africa today; initially the ANC saw hegemony mainly in institutional terms: It must put its cadres in charge not just of government but the army, civil service, business, schools, universities, provincial and local institutions of governance, scientific bodies, sporting associations, non-govermental organisationsNGOs, the police and every other socially commanding position (Pottinger 2008:37a). There is a powerful argument to be made that it is precisely in this situation where competent whites have been retired early, on a racially discriminatory basis, and young white academics turned away by universities that frankly tell them they are 'not hiring whites' (Johnson 2009:443b).

In conjunction to this, there are also acts of vandalism and protests over statues and symbols such as that of Queen Victoria in Port Elizabeth and Paul Kruger in Pretoria. The main argument advanced by proponents of the protests is that the statues have no place in a democratic dispensation. It is true that every generation has to discover its own mission; however, calling for the removal of these statues reflects intolerance. It furthermore contradicts the principle and concept of nation-building, because it is a sign of disrespect to the historical values of some members of the community.

This kind of behaviour should be declared abnormal within our society. A church that becomes a community in South Africa should propagate a sense of community in all spheres of life. This will include, among others, the effort of embracing those who are marginalised. Taking this statement into consideration, it is fair to say that a bill of rights with special provision for language, cultural, religious, educational and other rights that are essential for maintaining cultural identity can be deemed the best instrument up to this point in time to protect the rights of minorities and their members (Greenway \& Mashau 2007:13; Vorster 2004:171b).

\section{The tremendous decline in commitment and numbers in Dutch Reformed Churches}

Many traditional Afrikaans churches still struggle, with a number going out of existence as their constituents move on or grow old and pass away. Surveys speak of a thousand each week deciding to no longer attend church, half of whom are under the age of eighteen (Thwaites 2001:5a). According to Viola (2008:40), this paradigm is rooted in the attempt to practice Christianity without belonging to an identifiable community that regularly meets for worship, prayer, fellowship, and mutual edification. However, Basu (2005:97a) observes that the younger generation of today are rejecting the Gospel not because they consider all that is recorded to be false, but because the message no longer resonates with them. All this is not to say that there is nothing good to report. Ministers are at their post every Sunday, week to week, steadfastly preaching the Word to feed the faithful. Yet, the church as cultural alternative still fails to impress a society driving past on its way to work, shopping centres, sporting events or some other leisure activity (Thwaites 2001:6b). This disaster is compounded by the fact that Christians often congregate in clusters of common languages, similar history, experience or a common race. The unity within such group or community is onedimensional, with no real diversity.

Such people confirm themselves in communication. They talk to those who are like them, who think in basically the same way and who have the same possessions; in other words, they talk to themselves (therefore monological). As Joyner (2009:67) puts it, a primary factor that keeps many of us from fulfilling our calling is the tendency to try to minister to those we feel the most comfortable with or those whom we are the most similar to in flesh. This basic approach could be the first step on the bridge we cross to start compromising the Gospel (Joyner 2009:67). There is nothing wrong with this; Jesus also initially instructed the disciples to target their ministry (Mt 10:5-6). Similarly, Paul focused his ministry on Gentiles and Peter directed his to Jews (G1 2:7). Both ministries were needed important, and both were effective (Warren 1995:158).

There are certain risks. One danger is that of placing the unifying factors of culture, ethnicity, language and race above allegiance to our common Lord, Jesus Christ. It should also be mentioned that congregations and people tend to insulate themselves from others. They unwittingly and unintentionally move away from a mission of outreach in the community to an obsession with self-preservation. Such a tendency almost always produces ethnic pride and exclusivism that ends in pride and arrogance. The second danger is that of sect. A sect refers to a body of people who have chosen to separate themselves from the larger whole to follow their own tenets (Viola 2008:121-122). The conclusion that can be reached from the foregoing is that the monological group is not a community in the Biblical sense of the word. In short, the church that rises above the colour of a man's skin, his language and his seeming eccentric idiosyncrasies and accepts him as an equal brother is the church that reveals the love of Christ. As true Christians we are church members and citizens of a nation whose king is Christ and whose constitution is the Holy Bible (cf. Buchanan \& Hendricks 1995:189a).

\section{Legitimacy crisis}

In fairness towards the traditional Afrikaans churches it should be stated that in post-1994 South Africa they are faced with what Van Wyk (2005:647-682) calls a 'legitimacy crisis'. They were silent during the Apartheid years (more or less justified it) although there was the real danger of the politicising the Gospel, which is the identification of the Christian faith with a political programme (Strydom \& Wessels 2007:7b). This would be wrong for three reasons: The 
first is that it ignores the primary concern of the Christian faith, which is to love God - the 'first and greatest' commandment. Closely associated with this is the command to love our neighbours as ourselves. The second reason is that in a fallen world no one political programme can claim to be the expression of the will of God (Stott 2006:36b), and the third reason is that co-option of the churches by the State runs the risk that when a government is later discredited, so are the churches and their leaders that had given them uncritical allegiance. This has sometimes curtailed their ability to participate critically and constructively in what has become known as the second liberation (De Gruchy 1995:190; cf. Venter 1998:18b).

There is no doubt that this situation presents the Dutch Reformed Churches with a serious challenge. A case in point is how, in democratic South Africa, the ANC has continued to prop itself up through the invocation of history and selective memory to mask its massive governance failures. Regardless of what goes wrong (especially in government), it will be ascribed to Apartheid or, as Apartheid recedes over the distant horizon, it will be blamed on the 'heritage of Apartheid'. This is a classic case of history as political instrument of blackmail (Mashele \& Qobo 2014:78a). The challenge in post-1994 South Africa is how the traditional Afrikaans churches are to relate to and engage with a legitimate democratic state. In this era of democracy, these churches have vacillated between active engagement in nation-building initiatives and passivity and cynicism. It is important to mention that when the church distances itself from the agency of change; its members are abdicating their responsibilities as citizens. They also conceive their role in society in a group sense, and in this manner play into the disempowering device of the ANC of treating white South Africans as politically illegitimate and holding them collectively responsible for the past - a very dubious notion, since each individual is responsible for his own sins. It is as if the white middle class is politically frozen under an eternal curse cast by the ANC - that the sins of your father shall be visited upon you, up to a thousand generations of those whose skin has a white pigmentation (Mashele \& Qobo 2014:188b).

\section{Moral decay and moral regeneration}

Perhaps the most formidable contemporary challenge facing the Dutch Reformed Churches is the awakening or reawakening of the moral conscience of a nation, which, by many accounts, finds itself on the slippery slope of widespread moral decay. Principal problems like poverty and squalor; desperation; crime and violence; absolute inequality; rape; fraud and corruption; women and child abuse; disintegration of families; the high rate of HIV $\backslash$ AIDS infection; and the serious deterioration of the natural environment threaten to destroy South African society (Altbeker 2007:100; De Villiers 2003:25; Feinstein 2007:248; Gevisser 2009:221; Gumede 2005:162; Holden 2008:71; Pottinger 2008:121b; Richardson 2007:66; Saul \& Bond
2014:4). It is high time that we restore the pride of humanity by reminding ourselves that we should start to behave like moral human beings, by doing away with all sorts of perversion that prevail in society today (De Bruyn 1996:103; Koegelenberg 2003:1; Koopman 2002:451; Kotze 2000:431; Mashau 2005:3; cf. Ramphele 2012:3b) and by propagating a Biblical code of ethics (Kretschmar \& Hulley 1998:150-152b). The teaching ministry of the church is going to be subjected to one of its greatest tests, namely that of shaping sound moral character amongst its own constituencies (see Sekhaulelo 2007:31).

\section{The response of the Dutch Reformed Churches}

If we understand the teaching of Jesus Christ right, the Kingdom of God is not some kind of political utopia or social ideal or blueprint for a better society on earth. He made that perfectly clear when He said to Pilate: 'My kingdom is not of this world'(Jn 18:36). The Kingdom Jesus had in mind rests on the relationship a person has with God, by which his Spirit and power rules in the human heart (Williams 2004:10). This means that God's kingdom is not a place, but rather a relationship. It exists wherever people enthrone Jesus as Lord of their lives (Packer 1994:176). When He preached 'The kingdom of God is at hand (literally, 'has drawn near'). Repent, and believe the

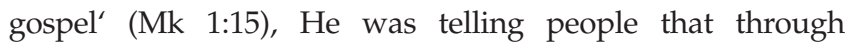
repentance and faith they could enjoy God's forgiveness and salvation and enter His eternal kingdom. It remains the essence of the message we have to preach today. We must present the spiritual aspects of God's kingdom first and foremost, whilst at the same time pointing out its practical implications in today's world (Kuiper 1961:114). Having given this context, the response of the Dutch Reformed Churches will be investigated in accordance with the following elements, namely, (1) the church as a holy community, (2) preaching of the gospel, (3) worship, (4) evangelism, (5) ministry to believers and (6) promoting the concept of Ubuntu.

\section{The church as a holy community}

The church should first and foremost be the servant of the King of the Kingdom of God. Obedience to God, as an essential part of Christian attitude, can thus be described as the core value of being a church in a modern-day liberal democracy. Holiness is commonly understood, in evangelical circles, as Christ-likeness and is a very important theme in the New Testament (Greenlee 2003:11a). As servant of Christ, the church is thus a unique community in the midst of many other human communities in modern society. It has its own character, calling and way of doing things. It is responsible for its actions not to humankind, but to Christ. The best way to describe this uniqueness is with the concept 'holiness'(J.M. Vorster 2007:256). Being holy means to be different from the world, not in a pietistic sense such as in Pentecostalism, but in the active pursuance of other principles and norms than those controlling modern society (Col 3:5-10; 1 Pt 1:15-16; 1 Cor 5:9-10).

The holiness of the church also implies the independence of churches. This is important, because one of the major reasons 
for the deformation of churches in the past was their alignment with the powers of the day. The freedom of the church would not therefore be measured by the privileges it enjoys in society, but rather by its willingness to be obedient to the will of God. The realisation that the church should stay independent of all political parties and ideologies will make it easier for the church to enter into discussion with the new ruling party. This will also restore the church's credibility and thereby make the ruling party increasingly prepared to listen to Christians.

\section{Preaching of the Gospel}

Along with the notion that the church only has one Head, is the idea that the church's only task is to live and carry out the Word of the Lord and that the church should carry this message to all people (Mt 28:19-20; Mk 16:15-16). In the same way, Paul also says that faith comes by hearing the Word of God ( $\mathrm{Rm} \mathrm{10:17).} \mathrm{The} \mathrm{ministering} \mathrm{of} \mathrm{the} \mathrm{Word} \mathrm{has} \mathrm{divine}$ authority, by merit of being the Word of God and not the word of any human being (De Bruyn 1998b:154). Warren (1995:224) opines that we do not have to make the Bible relevant - it already is. However, just as Jesus did, we have to show the Bible's relevance by applying its message personally to people's lives.

Put succinctly, the Gospel message should lead to repentance, confession of sin and also forsaking of sin (Horton 1992:95). Thus, the Good News offers lost people what they are frantically searching for: forgiveness, freedom, security, purpose, love, acceptance and strength. It settles our past, assures our future and gives meaning to today (Ande 2010:56; Bauckham 2003:11; Berkhof 1996:577; De Bruyn 1998a:154; Parker 1995:131). With the current rise and popularity of cults, false teachings and non-biblical philosophies, the mission of the Dutch Reformed Churches should be to return to the roots and foundation of our faith and present a 'balanced Biblical Christianity' that will not only be conducive to the spiritual unity of the church, but by cutting through the maze and semantics will bring out the essence of the full Gospel message that alone shows the way to salvation and eternal redemption (Cairns 1996:274; Dever, 2004:39; Warren 2006:11). Moreover, churches must proclaim the Gospel with courage and boldness. Their preaching must preserve the truth which we have received as our Christian heritage, based on historical origins and the revelation of God (2 Tm 3:14-17).

\section{Ministry to God (worship)}

In a relationship with God, the church's purpose is to worship Him in a genuinely personal response of humility, confession, repentance, devotion and praise (Young 1978:85). Grudem (2000:867a) states that worship in the church is not merely a preparation for something else; it is in itself fulfilling the major purpose of the church with reference to its Lord. Since worship is in part a response to what God has done in Christ, one of its keynotes is adoration (Davies 1966:118). There are also numerous other roles the church fulfils, such as the ministry of the sacraments in which the community of God's people is fully manifested. The Lord's Supper, for example, demands reconciliation and sharing among all those regarded as brothers and sister in the one family of God and is a constant challenge in the search for appropriate relationships in social, economic and political life. All kinds of injustice, racism, separation, prejudices and inequality are radically challenged when one shares in the body and blood of Christ (Eckhardt 2010:147).

\section{Evangelism}

God is not only concerned with personal salvation and the training of individual disciples, but also with establishing His Kingdom on earth. He wants us to become a new society a living community that will demonstrate, by its new lifestyle, new values and new relationship (Watson 1979:135). Hence, the present church is called out of all nations to do the same work of evangelising the world that Israel and others were called for in other ages (cf. Dake 1992:522; Senkhane 2002:27;). This evangelistic work of proclaiming the Gospel is the church's primary ministry to the world. Accompanying the work of evangelism is also a ministry of mercy, a ministry that includes caring for the poor and needy in the name of the Lord (Grudem 2000:867-868b). It should also be pointed out that part of the mandate for world evangelism is the Word of God. This implies that the evangelist must not only have a conception of human nature and the behavioural patterns of people, but it is absolutely essential (in order to convey the proper Biblical message) that he has a solid theological foundation (Basu 2005:168; Boff 1991:23; Claerbaut 1983:18; Dake 1992:522; Klaiber 1997:21; cf. Sookhdeo 1987:115).

\section{Ministry to believers (discipleship)}

Evangelism and discipleship complement each other; the one cannot be effective without the other (Choate 2000:52; Greenlee 2003:176b). Discipleship is a process of training and developing young and old believers into more mature Christians (cf. 1 Tm. 4:16; Tt 2:1; Col. 1:28). Paul's goal was not simply to bring people to initial saving faith, but to 'present every man mature in Christ'(Col 1:28; Eph 4:12-13). Christianity is not instinctive to anyone, nor is it picked up casually without effort. It is faith that has to be learned and therefore taught, some sort of systematic instruction (catechumenate) is thus an essential part of a church's life. One great need today is a renewal of systematic Christian instruction - catechetical teaching for adults. It need not be called that, nor need it take the form of rigid drilling according to predetermined formulae (which is how Protestants in former times taught their children), but opportunities must be created for folks in and just outside the churches to examine Christian essentials, because this is a prime need for so many (Ferguson 1991:5; cf. Guthrie 1998:18-19).

\section{Promoting the concept of Ubuntu}

Transforming society necessitates a look at the environment in which transformation takes place. In this regard, the 
concept of Ubuntu needs closer evaluation. For Rautenbach and Malherbe (2004:10) Ubuntu recognises a person's status as a human being, entitled to unconditional respect, dignity, value and acceptance from all members of the community in which that individual lives. The reverse is also true. The person has a corresponding duty to give the same respect, dignity, value and acceptance to each member of that community (Balshaw \& Goldberg 2005:44; Lessem \& Nussbaum 1996:70; cf. Mbigi \& Maree 1995:121; Ramphele 2012:36). Greenlee (2003:140c) states that God has gifted the church with gifts of compassion to provide a platform for His truth and love on earth. It is the task of the churches to develop love and justice ministries, which are sources of comfort and help to our neighbours. It is Ubuntu to be the church in South Africa today (Buchanan \& Hendricks 1995:179b; Richardson 2007:17b).

\section{Conclusion}

It is clear from the above that dialogue between the church and state on the matters of morality and ethics should be encouraged from the two camps for the good of South African community. This should be done on the basis that each institution could learn from the other. It is worthy to note that the church should therefore never forget its primary calling to pray, worship, evangelise and call people to follow Christ. Politically, it also needs to be aware that even as it seeks the very best for human society and studies the Word of God in pursuit of a Christian mind, it cannot enshrine Christian thinking into a particular political programme (see Stott 2006:37).

\section{Acknowledgements Competing interests}

The author declares that he has no financial or personal relationships which may have inappropriately influenced him in writing this article.

\section{References}

Altbeker, M.A., 2007, A country at war with itself: South Africa's crisis of crime, Jonathan Ball Publishers, Johannesburg.

Ande, T., 2010, A guide to leadership, SPCK Publishing Co., London.

Balshaw, T. \& Goldberg, J., 2005, Cracking broad-based black economic empowerment, Human and Rousseau, Pretoria.

Basu, K., 2005, The 21st century Christian and his end-time mission, Om Books, Secunderabad.

Bauckham, R., 2003, Bible and mission, Baker Academic, Grand Rapids, MI.

Berkhof, L., 1996, Systematic theology, Eerdmans Publishing, Grand Rapids, MI.

Biko, H., 2013, The great African society, a plan for a nation gone astray, Jonathan Ball Publishers, Johannesburg.

Boff, L., 1991, New evangelism: Good news to the poor, Editora Vores, Fotaleza.

Buchanan, D. \& Hendricks, J., 1995, Meeting the future, Knowledge Resources, Randburg.

Cairns, E.E., 1996, Christianity through the centuries: History of the Christian church, Zondervan, Grand Rapids, MI.

Choate, M.J., 2000, The church of the Bible, World Literature Publications, Cape Town. Claerbaut, D., 1983, Urban ministry, Zondervan Publishing Company, Grand Rapids, $\mathrm{Ml}$.

Dake, F.J., 1992, God's plan for man, Dake Bible Sales, Lawrenceville, GA. Davies, J.G., 1966, Worship and mission, Northumberland Press Limited, London. De Bruyn, P.J., 1996, Ethical perspective, PU for CHE, Potchefstroom.
De Bruyn, P.J., 1998a, Secularisation and the calling of the church, PU for CHE, Potchefstroom.

De Bruyn, P.J., 1998b, Your only comfort, The Heidelberg Catechism for mankind today, PU for CHE, Potchefstroom.

De Gruchy, J.W., 1995, Christianity and democracy: A theology for a just world, Cassell, London.

Dever, M., 2004, Nine marks of a healthy church, Grossway Books, Wheaton, IL.

De Villiers, D.E., 2003, 'A Christian ethics of responsibility: Does it provide an adequate theoretical framework for dealing with issues of public morality?', The International Journal of Bible, Religion and Theology in Southern Africa 82, 23-38.

Eckhardt, J., 2010, Ordinary people extraordinary power, Charisma House, Lake Mary, FL.

Feinstein, A., 2007, After the party: A personal and political journey inside the ANC, Jonathan Ball Publishers, Johannesburg.

Ferguson, S.B., 1991, Healthy Christian growth, The Banner of Truth Trust, Edinburgh. Gevisser, M., 2009, Thabo Mbeki: The dream deferred, Jonathan Ball Publishers, Johannesburg.

Giliomee, H. \& Schemmer, L., 1989, From Apartheid to nation-building, Oxford University Press, Cape Town.

Gouws, E. \& Kruger, N., 1996, The adolescent: An education perspective, Heinemann, Isando.

Greenlee, D., 2003, Global passion, OH Books, Secunderabad.

Greenway, R.S. \& Mashau, T.D., 2007, An eye that sees: Vision for urban mission, Thitshi Publishing, Potchefstroom.

Grudem, W., 2000, Systematic theology, Zondervan, Grand Rapids, MI.

Gumede, W.W., 2005, Thabo Mbeki and the battle for the soul of the ANC, Zebra Press, Cape Town.

Guthrie, W., 1998, The roots of true faith, Grace Publications Trust, London.

Heelas, P., Martin, D. \& Morris, P., 1998, Religion, modernity and postmodernity, Blackwell Publishers Inc.,Malden, MA.

Hofmeyr, J.W. \& Pillay, G.J., 1994, History of Christianity in South Africa, HAUM Tertiary, Pretoria.

Holden, P., 2008, The arms deal in your pocket, Jonathan Ball Publishers, Johannesburg.

Horton, M., 1992, Christ the Lord: The reformation and Lordship salvation, Baker Books House, Grand Rapids, MI.

Johnson, R.W., 2009, South Africa's brave new world: The beloved country since the end of Apartheid, Penguin Books, New York, NY.

Joyner, R., 2009, Church history: The first century, Morning Star Publications, Fort Mill, $\mathrm{SC}$

Klaiber, W., 1997, Call \& response: Biblical foundation of a theology of evangelism, Abingdom Press, Nashville, TN.

Koegelenberg, R.A., 2003, Breaking the grip of poverty and inequality in South Africa, EFSA, Stellenbosch.

Koopman, N., 2002, Christian ethics in post-Apartheid South Africa: A reformed perspective, University of Stellenbosch, Stellenbosch.

Kotze, H., 2000, 'An analysis of the value patterns of South Africa elites on selected moral issues', The International Journal of Bible, Religion and Theology in Southern Africa 75, 742-436.

Kretzschmar, L. \& Hulley, L., 1998, Questions about life and morality: Christian ethics in South Africa today, J.L Van Schaik, Pretoria.

Kuiper, R.B., 1961, God-centred evangelism: A presentation of the Scripture theology of evangelism, Hazel Watson and Viney Ltd., London,

Lessem, R. \& Nussbaum, B., 1996, Sawubona Africa, Sebra Press, Sandton.

Mashau, T.D., 2005, Love, courtship and marriage: Biblical solutions to problems, confronting African youths in the 21st century, Potchefstroom Theological Publications, Potchefstroom.

Mashele, P. \& Qobo, M., 2014, The fall of the ANC: What next?, Picador Africa, Johannesburg.

Mbigi, I. \& Maree, J., 1995, Ubuntu, Sigma Press, Pretoria.

McCauley, R. \& Steel, R., 1996, Power and passion, Cornelis Struik House, Cape Town. McGrath, A., 1992, Effective Christian apologetics, Inter-Varsity Press, Leicester.

Nefefe, M.S., 2000, 'Defining a dynamic view on churches unity with regard to mission: A special focus on the relationship between black and white reformed churches in Southern Africa', MA dissertation, PU for CHE, Potchefstroom.

Packer, J.L., 1994, Growing in Christ, Crossway Books, Wheaton, IL.

Parker, T.H.L., 1995, Calvin: An introduction to his thought, Geoffrey Chapman, London.

Popenoe, D., Cunningham, P. \& Boult, B. (eds.), 1998, Sociology (first South African edition), Prentice Hall, Midrand, South Africa.

Pottinger, B., 2008, The Mbeki legacy, Zebra Press, Cape Town.

Rainey, R.R. \& Magill, G., 1996, Abortion and public policy: An interdisciplinary investigation, Greighton University Press, Omaha, NE.

Ramphele, M., 2012, Conversation with my son and daughters, Penguin Group, Johannesburg.

Rautenbach, I.M. \& Malherbe, E.F.J., 2004, Constitutional Law, Butterworth, Durban. 
Richardson, J., 2007, Can you spare a bit of change? Responding to beggars: A Christian approach, Authentic Books, London.

Roberts, M. \& Brooman, J., 2001, South African 1948-2000: The rise and fall of Apartheid, Pearson Education Limited, London.

Ryan, C., 1990, Beyers Naude: Pilgrimage of faith, Wm. B. Eerdmans, Grand Rapids, MI.

Saul, J.S. \& Bond, P., 2014, South Africa: The present as history, Jacana Media, Johannesburg.

Sekhaulelo, M.A., 2007, 'The calling of the church and the role of the state in the moral renewal of the South African community', MA dissertation, North West University, Potchefstroom.

Senkhane, M.M., 2002, 'The role of biblical counselling in rebuilding the 'Poortjie' informal settlements', MA dissertation, PU for CHE, Potchefstroom.

Sookhdeo, P., 1987, New frontier in mission, Baker Book House, Grand Rapids, MI.

Stott, J., Issues facing Christians today, Zondervan, Grand Rapids, MI.

Strydom, J.G. \& Wessels, W.J., 2000, Prophetic perspectives on power and social justice, Biblia Publishers, Pretoria.

Thwaites, J., 2001, Renegotiating the church contact: The death and life of the 21st century church, Paternoster Press, Carlisle, Cumbria.

Van der Walt, B.J., 2007, Transforming power: Challenging contemporary secular society, Printing Things, Potchefstroom.

Van der Walt, B.J., 2010, At home in God's world: A transforming paradigm for being human and for social involvement, Printing Things, Potchefstroom.
Van der Walt, B.J. \& Swanepoel, R., 1996, Christian and democracy, Institute for Reformational studies, Potchefstroom University for Christian Higher Education, Potchefstroom.

Van Wyk, I.W.C., 2005, 'The political responsibility of the church: On the necessity and boundaries of the theory of two kingdoms', HTS Teologiese Studies|Theological Studies 61(3), 647-682.

Venter, A., 1998, Government \& politics in the new South Africa, J.L. Van Schaik, Pretoria, IL.

Viola, F., 2008, Reimagining church, David C. Cook Distribution, Colorado Springs, CO. Vorster, J.M., 2004, Ethical perspectives on human rights, Potchefstroom Theological Publications, Potchefstroom.

Vorster, J.M., 2007, Christian attitude in the South African liberal democracy, Potchefstroom Theological Publications, Potchefstroom.

Vorster, N., 2007, Restoring human dignity in South Africa: Christian anthropology in a new dispensation, Potchefstroom Theological Publications, Potchefstroom.

Warren, R., 1995, The purpose-driven church: Growth without compromising your message and mission, Zondervan, Grand Rapids, MI.

Warren, R., 2006, Rick Warren's Bible study methods: Twelve ways you can unlock God's Word, Zondervan, Grand Rapids, MI.

Watson, D., 1979, I believe in evangelism, Wm. B Eerdmans, Grand Rapids, MI.

Williams, P., 2004, Acts: Church on the move: An expositional commentary on the acts of the apostles, Day One Publications, Leominster, MA.

Young, J.T., 1978, The church alive and growing, Broadman Press, Fullerton, CA. 